\title{
Who Gets a Seat at the Table? A Framework for Understanding the Dynamics of Inclusion and Exclusion in Peace Negotiations
}

\author{
Author's manuscript \\ 21 July 2010 \\ David Lanz* \\ Swiss Peace Foundation, swisspeace \\ Sonnenbergstrasse 17; P.O. Box; CH-3000 Bern 7, Switzerland \\ (E-mail: david.lanz@swisspeace.ch)
}

* David Lanz is a PhD candidate at the University of Basel and works with the Mediation Support Project of the Swiss Peace Foundation, swisspeace. 


\begin{abstract}
Who gets a seat at the table and who does not is an important consideration for successful peacemaking. However, current research does not provide sufficient guidance for understanding the politics of participation in peace negotiations. The present article thus develops a conceptual framework for understanding these dynamics. Its central theme is that the inclusion or exclusion of a given actor in peace negotiations is affected by two independent factors. One factor pertains to the practical requirements of the peace process and addresses the following question: does the participation of a given actor augment the chance of reaching a sustainable peace settlement? The other factor relates to the normative dimension of peace talks: is the participation of a given actor consistent with the values of international mediators and sponsors of peace negotiations? The article argues that the dynamics of inclusion and exclusion result from the interplay of these two factors. The most straightforward situation for mediators is when practical requirements and international norms are mutually reinforcing. Difficulties arise from scenarios where practical effectiveness and norms contradict each other. This is the case when the involvement of a given person (or group) is imperative in terms of the peace process, but difficult to justify politically because this person has committed terrorist acts or is indicted by an international court.
\end{abstract}

\title{
Keywords:
}

International mediation, peace process, inclusion, exclusion, mediation support, peacebuilding, civil society, public participation, global justice, negotiating with terrorists, spoilers 


\section{Introduction: The Conundrum of Inclusion and Exclusion in Peace Negotiations}

Since the end of the Cold War, armed conflicts, military coups, refugee numbers, as well as war casualties have diminished significantly. According to Andrew Mack et al., "many of these changes could be attributed to an explosion of international activism ... that sought to stop ongoing wars, help negotiate peace settlements, support post-conflict reconstruction, and prevent old wars from starting again.” (Human Security Centre 2007: 1) The merits of such optimism aside, it is clear that international mediation as a practice in world politics has increased in the past 20 years. Consequently, scholars have tried to understand the circumstances in which mediation successfully produces a sustainable peace settlement. Among different factors - such as the timing of third-party interventions (Zartman 1989 [1985]), the type of mediation (Beardsley et al. 2006), and the skills of the mediator (Rubin 1992: 251) - the nature of the parties participating in peace negotiations is also of relevance. In other words, it matters who gets a seat at the negotiating table. Some authors have thus argued that mediation is likely to be more effective when the people at the table are recognized as the legitimate spokespersons of their parties (Bercovitch 2002: 262). Others have discussed the role of "spoilers," trying to understand when the exclusion of intransigent hardliners is beneficial for the peace process in the long run (Stedman 1997). These studies notwithstanding, current research on international mediation does not provide sufficient guidance for understanding the politics of participation in peace negotiations. These politics are characterized by the dynamics of inclusion and exclusiondefined here as a stakeholder's direct participation and involvement (or lack thereof) in the decision-making process of official peace negotiations. 
Who gets a seat at the table is not only a relevant academic question, it has significant political implications. It matters for conflict parties, given that their active participation in peace negotiations potentially generates domestic political support and international legitimacy and secures their influence in post-conflict state institutions. Participation in peace talks can also be problematic for conflict parties when domestic constituencies accuse them of selling out to the enemy. It also matters for states and international organizations acting as mediators since the groups that they are working with reflect on their prestige and values on the world stage. Not surprisingly, decisions about who gets a seat in peace negotiations often provoke controversy. Current discussions about whether or not Hamas should be included in the Middle East peace process are a case in point, as is the debate about the feasibility of negotiations with the Taliban in Afghanistan. On a more general level, peace practitioners have debated whether individuals indicted by the International Criminal Court (ICC) can legitimately participate in peace talks. Likewise, they are unsure about the implications of the recent US Supreme Court decision in the Holder v. Humanitarian Law Project case, which sets out that any activity with designated Foreign Terrorist Organizations (FTOs) constitutes a federal crime in the US under the so-called "material support law." The current situation is thus that the legal lines remain a blur, mediators follow ad-hoc practices, and international sponsors have yet to develop a coherent policy in regards to inclusion and exclusion in peace negotiations.

The premise of this article is that there are two independent factors which affect the inclusion or exclusion of a given actor in peace negotiations. The first relates to the practical requirements of the peace process and addresses the following question: does the participation of a given actor augment the chance of reaching a sustainable peace settlement? The other factor relates to the 
normative dimension of international mediation: is the participation of a given actor consistent with the values of international mediators and sponsors of peace negotiations? The dynamics of inclusion and exclusion thus result from the interplay between these two factors. The most comfortable situation for mediators is when practical requirements and international norms are mutually reinforcing. Difficulties arise from scenarios where practical effectiveness and norms contradict each other. This is the case when the involvement of a given person (or group) is imperative in terms of the peace process, but difficult to justify politically because this person has committed terrorist acts or is indicted by an international court.

In addressing these issues, the present article pursues two objectives. First, it seeks to make a modest contribution to the understanding of why certain actors are included while others are excluded from peacemaking efforts. Drawing on academic literature from negotiation theory as well as peace and conflict studies, the article proposes a conceptual framework for understanding inclusion and exclusion dynamics. This framework is not based on systematic empirical work, but presents a number of initial reflections upon which future research will hopefully elaborate. Second, this article aims to shed light on a number of questions that policy-makers and mediation practitioners grapple with in their work, offering some analytical guidance for them in the process.

\section{The Context of Inclusion and Exclusion in Peace Negotiations}

\section{The expansion of peacemaking after the end of the Cold War}

Bercovitch (2009: 343) defined mediation as

a process of conflict management, related to, but distinct from the parties' own negotiations, where those in conflict seek the assistance of, or accept an offer of help from, an outsider to 
change their perceptions or behavior and to do so without resorting to physical force or invoking the authority of law.

In the realm of international affairs, mediation, or 'peacemaking', involves the intervention in armed conflicts of external actors - states, international and regional organizations, nongovernmental organizations (NGOs), and individuals - with the aim of mitigating tensions between conflict parties in a process of negotiation (Zartman and Touval 2008). The foundation for mediation as an international practice was laid out in the UN Charter, in particular its Chapter VI regarding the pacific settlement of disputes. These provisions acquired meaning through Dag Hammarskjöld's ideas of 'preventive diplomacy' in the 1950s (Schachter 1962), although the polarization of world politics during the Cold War made it difficult to put them into practice (Jolly et al. 2009: 165-169). The end of the Cold War however, significantly altered this status quo and brought about a marked increase of the use of mediation in international conflicts (Babbitt 2009). Figures of the International Crisis Behavior Project show that in the 1980s approximately $30 \%$ of international crises received mediation; this number rose to $50 \%$ in the early and mid-1990s. Peacemaking declined somewhat around the turn of the millennium, but the latest data indicates a renewed surge in the last years (Centre for Humanitarian Dialogue 2007: 6-7). As a result, according to the Uppsala Conflict Data Program, the number of conflicts ending after a peace settlement rose from 21\% between 1946 and 1989 to 37\% from 1990 to 2005; at the same time, conflict termination via military victory diminished from 44 to $21 \%$ (quoted in Human Security Centre 2007: 19-20).

This development was further facilitated by the increasing institutionalization of mediation activities in the context of the advancement of the conflict resolution field since the end of the Cold War (Kriesberg 2001). This has meant that mediation as an activity has become 
increasingly embedded within the foreign policies of states as well as the programs of international organizations. Accordingly, bureaucratic entities dealing specifically with conflict resolution have been created, budgets made available, and political capital invested to promote mediation (Goetschel and Hagmann 2009). As a result, the practice of mediation has become normal in the sense that it constitutes a standard international response to armed conflicts in the world. This process of institutionalization has been reinforced in recent years with the creation of mediation support entities that offer permanent assistance to mediators in terms of logistics, knowledge management, training, and research. Mediation support has thus fostered a process of professionalization, which has helped to move international mediation beyond an ad hoc practice towards a professional field including a community of practitioners, established training programs, codes of conduct, and some accountability mechanisms. ${ }^{1}$

Within the United Nations (UN), the establishment of a Mediation Support Unit is one outcome of the growing institutionalization of mediation activities. Equally important was the high-level meeting of the UN Security Council in September 2008, during which states across the board praised mediation for its contribution to international peace and security (UN Security Council 2008). The UN Secretary-General subsequently published a report on mediation, which sets out the state of the art of the field (Ban 2009). Regional organizations are also expanding their mediation activities. In a recent concept paper, the European Union (EU) committed to playing "a more active role" in the area of mediation through "a more coordinated and focused

\footnotetext{
${ }^{1}$ Instrumental in the emergence of such guidelines has been the Mediation Support Network (MSN), which brings together the major players in the mediation support field: the Berghof Foundation (based in Germany), the Center for Peace Mediation (Germany), Conciliation Resources (UK), the Crisis Management Initiative (Finland), the Folke Bernadotte Academy (Sweden), the Centre for Humanitarian Dialogue (Switzerland), the Initiative on Conflict Prevention through Quiet Diplomacy (Canada), Swisspeace, the Center for Security Studies (Switzerland), the UN Mediation Support Unit, and the US Institute of Peace. For an overview of the MSN, see $<$ http://mcr.frameworks.usip.org/> [Accessed on 16 July 2010].
} 
approach" (Council of the European Union 2008: 2). Likewise, the Organization for Security and Co-operation in Europe (OSCE) is currently undertaking efforts to develop mediation support through its Conflict Prevention Centre (Fugfugosh 2008), and there are plans to strengthen the mediation capacity of the African Union (Nathan 2008). Moreover, small and medium states, such as Norway and Switzerland, who have been proactive in this field since the 1990s, have furthered their engagement in conflict resolution in the last few years. ${ }^{2}$ Also of note is the entry onto the mediation scene of non-Western states, such as Qatar, who mediated between rival Lebanese factions in 2008 and who currently sponsors the Darfur peace talks. Burkina-Faso's role bears mentioning as well: the country has successfully brokered a peace accord in Côte d'Ivoire in 2007 and it initiated the high-level meeting of the UN Security on mediation in 2008. The expansion of international mediation has also been fostered by a number of NGOs that have emerged as 'mediation entrepreneurs.' Groups like the Carter Centre, the Centre for Humanitarian Dialogue, and the Crisis Management Initiative are today professional organizations, with experienced staff and significant budgets (Taulbee and Creekmore 2003; Huber 2004). They actively seek mediation opportunities and are often tasked with getting involved in situations that are too politically sensitive for states (Aall 2007; Chigas 2007; Bartoli 2009).

A detailed analysis of why the mediation field has expanded so significantly since the end of the Cold War goes beyond the scope of this article. As a hypothesis however, we argue that this expansion is underpinned by both material and normative developments in world politics. On the material side, it is notable that the cost of war for states has risen significantly, both in terms of

\footnotetext{
${ }^{2}$ In Switzerland, for example, the Parliament in 2004 adopted a specific bill on civilian peacebuilding, which provides a legal framework and financing model permitting long-term commitments by the Swiss government in the field of conflict resolution. (For details, see Swiss Federal Department of Foreign Affairs 2007).
} 
the actual costs of fighting a war as well as in terms of the tolerance of casualties in domestic public opinion (Nye 2004: 18-24). The use of military power in foreign policy has diminished, but at the same time international conflicts still pose a security threat for many states. In particular since September 11, there is a growing perception that more should be done to address the sources of instability in the developing world, considering the threat that they pose to the security of western states (Fearon and Laitin 2004; Krasner and Pascual 2005). Given its relative cost-effectiveness, international mediation has thus emerged as an attractive instrument of conflict management.

As far as the normative structure of world politics is concerned, the erosion of the absolute principle of sovereignty has had an important role in paving the way for increased international intervention in armed conflicts. In the last 20 years, the threshold for responsible behavior of sovereign states has been elevated to include actions inside their territory. This includes a minimum respect for human rights and the protection of their citizens from grave physical harm. Where governments are unwilling or unable to live up to this responsibility, the international community has a duty to intervene (Deng et al. 1996; Evans and Sahnoun 2001). International mediation does not contradict sovereignty per se - indeed, mediation is by definition noncoercive and requires the acquiescence of the conflict parties. However, it does constitute a form of external intervention in the internal affairs of a country, which previously may have been considered unacceptably intrusive. The expansion of international mediation may also have been fostered by an emerging 'peacemaking norm,' which refers to the idea that armed conflicts should be solved through non-violent means, such as negotiations, rather than through the use of military force. Future research will have to address whether or not this is a plausible concept. 
What is striking, however, is that when violence breaks out today, states generally call for peace negotiations as well as offering their assistance via mediation. Arguments, such as Luttwak's (1999) proposal to "give war a chance" seem to be increasingly marginal and are even considered unethical. Of course, this does not mean that wars no longer occur or that the use of military force as a policy instrument has become unacceptable. By and large however, the expected way of resolving armed conflicts on the international stage is through negotiation and mediation.

\section{The convergence of international norms and practical requirements}

What does the expansion of mediation since the end of the Cold War mean for the dynamics of inclusion and exclusion? One consideration is that when states and international organizations get involved and invest political capital in mediation processes, these processes move away from a strictly domestic political logic and become a matter of international concern. Thus, when international mediators get involved in peace negotiations, we can expect them to project their own interests and values onto these processes. This is not to say that mediators are all powerful or that they dominate what happens in peace negotiations. While the leverage used by mediators varies, they generally do not use coercive means to impose an agreement on the parties.

However, international mediators $d o$ in fact shape the mediation process, despite the rhetoric of neutrality with which mediators often coat their interventions. They do so, among other things, by setting the agenda; providing training to conflict parties; bringing in technical experts; and drafting peace agreements. 
The rationale of such influence is twofold. One is that peace negotiations are showcases through which the world views states and international organizations acting as mediators. Many states see peacemaking as a way to generate prestige on the world stage and therefore international norms are particularly important to them. Nordic states, for example, have adopted the identity of peacemakers and therefore act as "norm entrepreneurs" promoting conflict resolution as an integral part of their foreign policies (Ingebritsen 2002). Others see mediation as a source of "soft power," which helps to build their legitimacy in international affairs (Nye 2004). ${ }^{3}$ Given the normative interests of mediators, it is not surprising that many peace agreements since the end of the Cold War have contained extensive provisions for human rights (Bell 2000, 2006; Babbitt and Lutz 2009). In addition to the issues under discussion, the stakeholders who participate in peace negotiations are another important consideration. Participating in peace negotiations undoubtedly confers legitimacy on stakeholders and therefore international mediators may be reluctant to grant recognition to actors whose reputation is excessively tarnished. Although mediation generally involves engaging people with blood on their hands, certain actors are so stigmatized that it is politically difficult for international mediators to include them.

However, international norms are not the sole concern of mediators as they are also genuinely interested in facilitating a sustainable peace settlement to end civil wars. Obviously, the positive effects of mediation only accrue when mediators successfully broker a peace settlement which then catches the attention of the world press. Also, given that mediation is a crowded field today,

\footnotetext{
${ }^{3}$ A recurrent term in this article, the notion of 'legitimacy,' according to Franck (1990: 3, 19), provides an answer to the question: "Why do powerful nations obey powerless rules?", namely because of "the perception of those addressed by a rule or a rule-making institution that the rule or institution has come into being and operates in accordance with generally accepted principles of right process." Herd (1999) distinguishes legitimacy as a mechanism of social control from coercion and self-interest.
} 
mediators can be replaced if the conflict parties or international sponsors doubt the quality of their work. Therefore, the second rationale for influencing a mediation process is to maximize the chances that it actually produces a sustainable peace agreement. As far as the dynamics of inclusion and exclusion are concerned, this implies a practical imperative, rooted in Realpolitik: Only stakeholders who add value to the process and augment the chances of reaching a sustainable settlement should be given seats at the table, regardless of normative factors.

Evidently, there are some palpable tensions between the two above-mentioned dimensions of contemporary peacemaking: international norms and practical requirements. Indeed, it appears that the conundrum of international mediation stems from the convergence of a utilitarian and a normative logic. The dynamics that result from this interaction play out in terms of the issues under discussion as well as the actors participating in peace negotiations.

\section{Factors of Inclusion and Exclusion in Peace Negotiations}

Given the two dimensions of peacemaking, normative and practical, it is useful to further differentiate two sets of factors within each dimension in order to build our framework. As such, one set of factors regarding the normative dimension favors inclusive peace negotiations, while the other supports exclusion - and vice versa for practical requirements. Clearly, there are no hard-and-fast rules for the inclusion and exclusion of stakeholders in peace negotiations. Rather, there are arguments which are at the core of the dynamics of inclusion and exclusion. Table 1, presented below, provides a summary, while the following paragraphs elaborate on different factors of inclusion and exclusion in peacemaking. These factors draw on academic analyses 
from peace and conflict studies that have, to some extent, been incorporated into the policy and practice of international mediation.

Table 1: Factors of inclusion and exclusion in peace negotiations

\begin{tabular}{|c|c|c|}
\hline & Factors of inclusion & Factors of exclusion \\
\hline $\begin{array}{l}\text { International } \\
\text { norms }\end{array}$ & 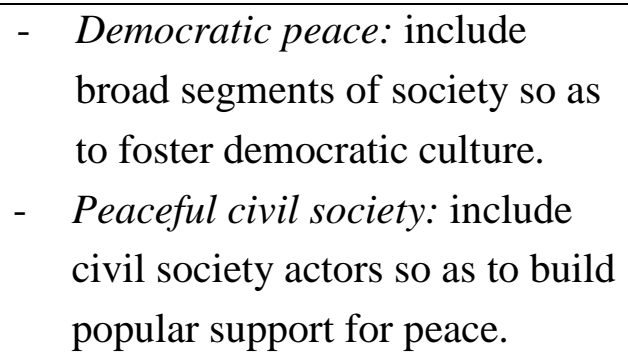 & $\begin{array}{l}\text { Global justice: exclude alleged } \\
\text { perpetrators of mass atrocities } \\
\text { to ensure their accountability. } \\
\text { - } \quad \text { War on terror: exclude } \\
\text { terrorist groups as a means of } \\
\text { de-legitimization. }\end{array}$ \\
\hline $\begin{array}{l}\text { Practical } \\
\text { requirements }\end{array}$ & $\begin{array}{l}\text { Realpolitik: include the most } \\
\text { powerful military actors who } \\
\text { could undermine peace. } \\
\text { - Implementation perspective: } \\
\text { include non-military actors } \\
\text { whose support is crucial to } \\
\text { consolidate peace in the long } \\
\text { run. }\end{array}$ & $\begin{array}{l}\text { - Keep it simple: exclude actors } \\
\text { that unnecessarily complicate } \\
\text { peace negotiations. } \\
\text { - } \quad \text { Spoilers: exclude intransigent } \\
\text { hardliners who seek to } \\
\text { undermine a peace process. }\end{array}$ \\
\hline
\end{tabular}

The normative dimension of inclusion and exclusion

As far as the normative dimension of peace negotiations is concerned, there are two arguments in favor of inclusive processes that involve broad participation from military and civilian actors.

The first argument pertains to the well-known democratic peace thesis: A liberal democratic system of governance fosters internal legitimacy as well as a peaceful international order. A democratic state is thus at peace with itself as well as its neighbors (Doyle 1983). This finding leads to a normative prescription: the international community should help transform countries emerging from wars according to a "liberal peace framework" including free and fair elections, the rule of law, respect for human rights, the separation of power, and a market economy (Richmond 2005; Paris 2004; Barnett 2006). Liberal peacebuilding further requires the 
cultivation of a culture of democracy. Public education is a means to this end, as is public participation in political forums. This applies, for example, to efforts to draw up a new constitution - a process that may be part of official negotiations or take place after a peace agreement is signed (Hart 2001). In this context, Samuels (2006: 7, 8) argues that public participation fosters "a process of democratic education," whereas exclusive processes "should be avoided as they undermine the quality of the democracy created in the long-term." With regards to peace negotiations, these arguments suggest a normative preference for peace negotiations that include broad segments of society, including political parties, Diaspora groups, eminent individuals and civil society. 'Elite pacts' between the most powerful military players are therefore not acceptable.

Related to the democratic peace is the idea of the peaceful civil society. Accordingly, civil society embodies a true democratic potential, which needs to be tapped in order to achieve “sustainable reconciliation in divided societies" (Lederach 1997; Paris 2004: 160-161). Applying this argument in the context of official peace negotiations, Wanis-St. John and Kew (2008: 11) remarked that "rarely do local civil society groups get a seat at the negotiation table." While such exclusion helps mediators streamline the process, it has negative feedback effects in the long run (Idem: 13). In this regard, Wanis-St. John (2006) argued that the "back-channel" nature of the Palestinian-Israeli peace talks in 1993 as well as the exclusion of civil society from the negotiations, prevented the formation of a broad-based pro-peace constituency. This contributed to failures in the implementation of the Oslo Accords and ultimately undermined the process as a whole (Idem). Another argument for civil society inclusion contends that conflict parties are insufficiently accountable in peace processes without public participation (Barnes 2002). This 
induces them to opt for an opportunistic, quick-fix peace deal, which does not tackle the root causes of conflict and fails to establish the foundation for sustainable peace (Idem). In short, the idea is that public participation in peace negotiations enhances the legitimacy of both the process and the outcome, effectively increasing the likelihood of durable peace. Relevant for our purposes is the normative argument that civil society actors should be included in peace negotiations.

International norms also provide arguments for the exclusion of certain actors from official peace negotiations. One argument pertains to international efforts to establish a functioning system of global justice. This refers to the idea that people who committed acts qualifying as war crimes, crimes against humanity, or genocide must be held accountable regardless of when and where these crimes took place (Lutz and Sikkink 2001; Neier 2001). Global justice advocates hope that such accountability leads to a deterrence effect by "shifting the borders of legitimacy and thereby changing the cost-benefit calculus of using atrocities as an instrument of power" (Akhavan 2005: 419). International criminal justice does not specifically interfere with peace negotiations except when perpetrators are offered amnesties for the above-mentioned crimes (Bell 2006). Legality aside, global justice norms make it nonetheless difficult to engage groups that are alleged to have committed mass atrocities, especially when charges were brought against these groups in an international court. Such indictments often mean that alleged war criminals are isolated internationally, and mediators will find it difficult to mobilize support for peace negotiations with these same actors. Advocates of international criminal justice do acknowledge that their project may complicate peacemaking efforts. In this regard, Richard Goldstone tellingly stated: "If you have a system of international justice, you've got to follow through on it. 
If in some cases that's going to make peace negotiations difficult, that may be the price that has to be paid" (quoted in McGreal 2007: 14). The normative argument associated with global justice, therefore, is that peace negotiations should not result in the legitimization of alleged war criminals.

Another factor of exclusion relates to the war on terror, which has dominated the foreign policy of the US and other states since September 11. Most observers emphasize the geopolitical rationale of the war on terror and so it may seem curious to consider its normative aspects. However, the war on terror includes a strong symbolic dimension insofar as it attempts to marginalize certain actors by labeling them 'terrorists' - a label with a strong stigma attached to it (Bathia 2005). The war on terror, therefore, is a struggle to de-legitimize terrorist groups, just as much as to militarily incapacitate them. One aspect of this struggle is to categorically exclude such groups from international negotiations, based on the belief that negotiations would generate goodwill for alleged terrorists. In the aftermath of September 11, the slogan 'We don't negotiate with terrorists!' has gained credence among many governments (Toros 2008). As a result, it has become politically difficult for international mediators to engage groups associated with terrorism (Zartman 2003a). Such engagement may even be illegal under US law, as a recent decision by the US Supreme Court suggests. In the Holden v. Humanitarian Law Project case, the Court provided a far-reaching interpretation of the US "material support law," basically declaring illegal any interaction of third parties with designated FTOs, including training, advocacy, and expert advice (Supreme Court of the United States 2010). ${ }^{4}$ What is more, the material support law makes a controversial claim of extraterritorial jurisdiction, which raises the

\footnotetext{
${ }^{4}$ The authority to designate Foreign Terrorist Organizations rests with the US Secretary of State, although it is subject to judicial review. For the current list of FTOs, see <http://www.state.gov/s/ct/rls/other/des/123085.htm> [Accessed on 18 July 2010].
} 
possibility that acts committed by non-US citizens and those occurring outside US territory are punishable under this law (Colangelo 2007). The legal implications of the Supreme Court decision for international mediators remain unknown, but it is already clear that their ability to include groups that are considered to be terrorists will be restricted. ${ }^{5}$ In sum therefore, the war on terror as a normative argument calls for the exclusion from peace negotiations of groups alleged to have committed acts of terrorism.

\section{The practical dimension of inclusion and exclusion}

Turning to the practical requirements of peace negotiations, two related arguments can be mentioned with regards to inclusion. The first one is related to the basic realist argument that it is necessary to deal with the reality of power, i.e. Realpolitik, rather than with lofty norms and values (Carr 2001 [1939]). In the area of peace negotiations, the realist perspective finds expression in Zartman's (1989 [1985]) concept of the "ripeness of conflict" (Kleiboer 1994). Accordingly, armed conflicts can only be resolved when parties face a "mutually hurting stalemate," that is "a situation in which neither side can win, yet continuing the conflict would be very harmful to each," and when they see a negotiated settlement as a "way out" (Zartman 2003b). At this point, mediators can step in and broker a compromise that reflects the balance of power between the strongest military actors in a given conflict setting. A Realpolitik perspective thus emphasizes the practical need to include in peace negotiations the most powerful players in a conflict, usually military actors.

\footnotetext{
${ }^{5}$ Not surprisingly, the conflict resolution community in the US is opposed to the ruling of the Supreme Court. Former US President Jimmy Carter, for example, stated: "We are disappointed that the Supreme Court has upheld a law that inhibits the work of human rights and conflict resolution groups. The "material support law" - which is aimed at putting an end to terrorism - actually threatens our work and the work of many other peacemaking organizations that must interact directly with groups that have engaged in violence. The vague language of the law leaves us wondering if we will be prosecuted for our work to promote peace and freedom." Available from <http://www.aclu.org/national-security/supreme-court-rules-material-support-law-can-stand> [Accessed on 21 July 2010].
} 
A similar argument relates to the implementation perspective of peace processes. According to Stedman (2002: 2), "there was ... a tendency to conceive of conflict resolution in a linear fashion, where successful negotiation signaled an irreversible reduction in conflict." However, "far from being a time of conflict reduction, the period immediately after the signing of a peace agreement seemed fraught with risk, uncertainty, and vulnerability" (Idem). Therefore, policymakers and practitioners have to look beyond peace agreements and focus on the subsequent phase of implementation. For mediators, this perspective requires a stronger awareness that what happens during peace negotiations has implications on peace consolidation in the long run. Unfortunately, analysts of implementation have not specifically tackled the question of inclusion and exclusion, although Stedman (Idem: 9) found that peace consolidation is more likely with "an agreement that is the culmination of years of problem-solving, relationship-building, and inclusion." From this, we can deduce the following practical argument: actors that potentially play an important role in supporting a peace process in the postagreement phase should be included in peace negotiations. Powerful political actors are important in this regard, in addition to military stakeholders.

The argument that only the most powerful actors should be included in peace negotiations has a logical corollary: Other actors should be excluded in order not to overextend peace talks that tend to be fragile constructs to begin with. In other words, mediators should keep it simple, both in terms of the issues under discussion and the actors they invite to participate. This argument finds ample support in negotiation theory. Axelrod (1984) demonstrated the conditions under which two self-interested actors in a competitive setting are able to establish cooperation with 
each other. Thus, increasing the number of negotiators "will not sustain cooperation very well because the players have no way of focusing their punishment on someone in the group who has failed to cooperate" (Axelrod 1997: 7). Along similar lines, Raiffa (2004) observed that the inclusion of additional parties augments the complexity of the negotiation process and thus reduces the probability of arriving at an agreement. Cunningham (2006: 875) provides further support: Based on extensive empirical data, he finds that "more parties involved in conflict make civil wars more difficult to resolve through negotiation and therefore of longer duration." He provides several explanations: multiple actors reduce the range of acceptable agreements; they exacerbate information asymmetries; they frequently shift alliances; and they often opt for noncooperation in the hope of obtaining a better agreement later (Idem). The practical lesson from this analysis is straightforward: mediators should focus on the main armed combatants and exclude other actors so as not to unnecessarily complicate peace negotiations.

A final argument emerges from discussions regarding spoilers in peace processes, defined by Stedman (1997: 5) as "leaders and parties who believe that peace emerging from negotiations threatens their power, worldview, and interests, and use violence to undermine attempts to achieve it." Effective peacemaking demands that mediators and international sponsors of peace processes settle on the most appropriate strategy for dealing with spoilers. In some instances, international custodians can accommodate spoilers, inducing them to participate in peace negotiations. In the case of "total spoilers" - actors that can under no circumstances be integrated in a peace process - the most beneficial strategy is one of marginalization. Excluding spoilers from peace negotiations is one element of this strategy (Idem: 14-16). Stedman's analysis has been criticized, for example by Zahar (2003: 114), who argued that "building sustainable peace 
requires bringing the parties threatening to peace into the negotiation process ... and preventing them from developing incentives to renege during the implementation stage" (see also Greenhill and Major 2006/07). However, Stedman's argument remains influential in policy-making circles: if a stakeholder behaves in an absolutely intransigent fashion, it is practically beneficial to exclude this actor from peace negotiations.

\section{The Dynamics of Inclusion and Exclusion in Peace Negotiations}

The combination of the above-mentioned factors yields a generic conceptual framework, which should allow us to better understand the dynamics of inclusion and exclusion. Basically, peacemakers' normative and practical preference for either inclusion or exclusion determines their approach towards each stakeholder. The framework thus generates four scenarios: two, in which norms and practical effectiveness are in phase and two others, where they contradict each other. Table 2 provides a summary of these scenarios, while the following section provides several short empirical examples as illustration.

Table 2: Scenarios of inclusion and exclusion in peace negotiations

\begin{tabular}{|l|l|l|}
\hline Practical & INCLUDE & EXCLUDE \\
\hline INCLUDE & $\begin{array}{l}\text { Scenario 1: Include-include } \\
\text { International norms provide } \\
\text { arguments for the inclusion of a } \\
\text { crucial stakeholder. }\end{array}$ & $\begin{array}{l}\text { Scenario 2: Include-exclude } \\
\text { International norms suggest } \\
\text { including a stakeholder, but this } \\
\text { complicates peace negotiations. }\end{array}$ \\
\hline EXCLUDE & $\begin{array}{l}\text { Scenario 3: Exclude-include } \\
\text { International norms suggest } \\
\text { exclusion, although the participation } \\
\text { of a stakeholder is crucial to } \\
\text { achieving peace. }\end{array}$ & $\begin{array}{l}\text { Scenario 4: Exclude-exclude } \\
\text { International norms provide } \\
\text { arguments for the exclusion of a } \\
\text { spoiler. }\end{array}$ \\
\hline
\end{tabular}




\section{Four scenarios of inclusion and exclusion}

In some peace processes, distributing seats at the table is a straightforward exercise. This is the case when the parties to a conflict are few in number, hierarchically organized, and relatively respected internationally; additionally, they have a coherent political agenda and significant popular support. However, in many contemporary conflicts, the belligerents are fragmented, removed from civil society, and disparaged internationally. Under these conditions mediators have to address a number of questions regarding inclusion and exclusion: Given a field of many armed groups, which should be invited to participate in peace talks? Do representatives of civil society and political parties get a seat at the table? How should mediators deal with terrorist groups or groups whose leaders are indicted by an international court? As they evaluate these issues, international mediators are confronted with two fundamental questions: Does the participation of a given actor augment the chance of reaching a sustainable peace settlement? And: is the participation of a given actor consistent with international norms and values? Four scenarios of inclusion and exclusion can be distinguished on this basis.

The clearest case is given by Scenario 1(include-include), where both of the above-mentioned questions are answered affirmatively. This means that there is a practical rationale for inclusion, insofar as the participation of a given actor increases the chances of achieving a sustainable peace settlement, and this rationale is supported by the actor's international reputation. The peace process in Nepal is a case in point. Initially, the peace talks involved the two main actors on the battlefield: the Maoist rebels and the King who controlled the powerful Nepalese army. However, the talks quickly ran into a deadlock. This changed as a result of the popular uprising of April 2006, after which representatives of the main political parties in Nepal, united in the 
Seven Party Alliance (SAP), were brought into the negotiations (International Crisis Group 2006). The participation the SAP - whose inclusion was supported by international norms related to democratic peace as well as peaceful civil society - helped to create a new dynamic, culminating in the signing of the Comprehensive Peace Accord of November 2006, which effectively ended Nepal's civil war (Baechler 2006). Nepal thus exemplifies the useful role of include-include dynamics in terms of giving support to the participation of non-military actors when the negotiations between military belligerents are deadlocked or unlikely to produce a sustainable peace settlement.

Similarly unambiguous is Scenario 4 (exclude-exclude), where both questions are answered negatively. This scenario refers to situations where the inclusion of an actor is problematic in terms of international norms - either because the actor is perceived to be a terrorist or accused of war crimes by an international court. At the same time, inclusion would be counter-productive in terms of effective peacemaking, given the actor's spoiling motivation or military marginality. An example of this dynamic is the role of the Bosnian Serb militia during the war in the Balkans in the 1990s. At first, the international community opted for a pragmatic peacemaking strategy that included negotiations with all conflict parties, including the leaders of the Bosnian Serb militia, Radovan Karadzic and Ratko Mladic (Hazan 2004). However, the U.S. government's lead mediator, Richard Holbrooke, did not invite the two men for the final peace talks in Dayton, focusing instead on negotiations between the Serbian, Croatian, and Bosnian governments. ${ }^{6}$ This decision was sensible from a practical perspective, for the Bosnian Serbs were neither interested

\footnotetext{
${ }^{6}$ In his book To End a War, Holbrooke (1998: 107) recounts a conversation he had with the Serbian President Milosevic in the run-up to the Dayton talks. When Milosevic said "You need Karadzic and Mladic to make peace", Holbrooke replied: "That is your problem. Karadzic and Mladic cannot go to an international conference. They will be arrested if they set foot in any European country. In fact, if they come to the United States, I would gladly meet them at the airport and assist in their arrest."
} 
in a peace settlement, nor was their inclusion really necessary, given Belgrade's leverage over them. Furthermore, the stigmatization of the Bosnian Serb leaders as a result of the indictment of Karadzic and Mladic by the International Tribunal for the Former Yugoslavia (ICTY) proved a useful justification for their exclusion. The Dayton talks thus illustrate that international norms can provide arguments for peacemakers to justify the practically sensitive exclusion of a stakeholder from peace negotiations.

More difficult is Scenario 2 (include-exclude), where the inclusion of an actor is the right thing to do as far as values are concerned, but this potentially has negative consequences on the effectiveness of peace negotiations. Here, norms and practicality contradict each other, and this poses a difficult dilemma for mediators. If civil society and moderate political parties are excluded, peace negotiations might be perceived as cynical elite pact-making and consequently lack international support. If all of these actors are included, however, the negotiations become nearly impossible to manage for mediators. Also, as Cunningham (2006) reminds us, inclusive peace negotiations exacerbate information asymmetries, tactical intransigence, and shifting alliances, thereby decreasing the likelihood of reaching a workable agreement. Some authors have cited the 1993 Arusha talks to end the Rwandan civil war as an example of the flaws of inclusive peacemaking. According to Clapham (1998:205), the Arusha accords "gave an extraordinary weighting in the proposed transitional government to parties with no military strength, no control of territory, and an as yet undetermined level of popular support.” By focusing the peace negotiations on moderate, but ultimately powerless actors, and by excluding the more difficult but powerful players such as the Hutu extremists, international peacemakers facilitated a peace agreement that could never be implemented. Even worse: as Clapham argues, 
the Arusha Accord made Hutu extremists anticipate a loss of power, causing a violent backlash that eventually culminated in the Rwandan genocide in April 1994 (Ibid).

The most typical contradiction between the effectiveness and normative compliance of peace talks is posed by Scenario 3 (exclude-include). Here, effective peacemaking requires the inclusion of an actor as a consequence of its popular support or military might. However, such inclusion is problematic in terms of international norms because of the stigma attached to groups using terrorism or being indicted for war crimes. Indeed, the emergence of the war on terror since September 11, along with the institutionalization of international criminal justice through the establishment of the ICC, have made the 'exclude-include' scenario a frequent challenge for international peacemakers. The Palestinian organization Hamas is the best-known example in this respect. Hamas controls significant territory through its coercive apparatus and the group has major popular support, as demonstrated by the 2006 elections in Palestine. Against this background, a peace deal in the Middle East seems inconceivable without including Hamas. However, the U.S. government and the EU consider Hamas a terrorist group and refuse to deal with it in the context of peace negotiations (Gunning 2004). The merits of this determination aside, the exclusion of Hamas significantly complicates the peace process in the Middle East. ${ }^{7}$ A similar dilemma was posed by the Ugandan Lord's Resistance Army (LRA), whose senior commanders were indicted in 2005 by the ICC on war crimes and crimes against humanity charges. The Government of Southern Sudan, on whose territory the LRA operated, subsequently instigated peace talks. At the outset, the Southern Sudanese found it difficult to find

\footnotetext{
${ }^{7}$ This is precisely why a group of eminent international peacemakers, including Paddy Ashdown, Shlomo Ben-Ami, Alvaro de Soto, Gareth Evans, John Hume, Chris Patton, and Thorvald Stoltenberg signed an open letter in February 2009. According to the signatories, "it is of vital importance to abandon the failed policy of isolation and involve Hamas in the political process." Available from <http://www.spiegel.de/media/0,4906,20042,00.pdf $>$ [Accessed on 18 July 2010].
} 
international support for the talks because many states considered peacemaking as an obstruction of justice that would reflect negatively on them (Lanz 2007). The negotiations eventually did take place, although the LRA finally withdrew from them.

\section{Two caveats}

Before concluding, two caveats have to be mentioned with regards to our framework for inclusion and exclusion. First, the framework does not claim that international mediators alone decide about matters of inclusion and exclusion. Indeed, peace negotiations are sometimes instigated domestically and international actors only have a marginal role. Therefore, it is absolutely possible for an actor to be included even though in the international realm, arguments

for its exclusion prevail. However, mediators often have significant leverage over conflict parties and as a consequence, they have a say as to who is included in peace talks. Also, international acquiescence to the distribution of seats at the table is probably necessary to generate international legitimacy for conflict parties - indeed, this represents a key function of peace negotiations.

The second caveat is that the scenarios should not be interpreted as being static. Rather, they are highly dynamic, as the attitude of international peacemakers with regards to an actor can change over time. The Bosnian Serbs, for example, initially took part in peacemaking efforts, but as reports of their horrific crimes became public, they were increasingly marginalized. Another example of changing inclusion-exclusion dynamics is the Palestine Liberation Organization (PLO), which was initially excluded on the grounds of its terrorist activities, before becoming an acceptable interlocutor in the eyes of most states. Another dimension of the dynamics of 
inclusion and exclusion is the fact that positions regarding stakeholders can differ from one government to another. Governments of some Arab states, for example, evaluate the role of Hamas in the Middle East peace process differently than their US counterpart. Therefore, the scenarios presented above represent the dominant (rather than an absolute) international opinion at a given point in time.

\section{Conclusion: Defending "Peacemaking Space"}

This article has argued that the dynamics of inclusion and exclusion in peace negotiations - the question of who gets a seat at the table - are affected by two independent dimensions. One pertains to the practical requirements of peacemaking, basically the desire of mediators to include all actors who are critical for reaching and subsequently implementing a peace agreement. The other dimension is normative in the sense that peacemakers want their engagement in peace processes to be in sync with the values and norms they promote on the global stage. As these two dimensions interact, different scenarios for inclusion and exclusion emerge. These scenarios carry a number of implications for international mediators and supporters of peace negotiations. When norms and practical requirements of peace negotiations are aligned - both pointing to either the inclusion or exclusion of a given stakeholder - mediators can bring to bear normative arguments to justify the practically sensible inclusion and exclusion of a stakeholder. International norms thus support the practice of peacemaking. However, this is not always the case. Increasingly, peacemakers are confronted with situations where norms work against and even undermine effective peace negotiations. This poses serious dilemmas to peacemaking practitioners. 
There are, however, a number of remedies to circumvent these dilemmas. For exclude-include scenarios, when mediators cannot but should involve a given actor, back-channel talks can be a helpful instrument. Thus, peace talks with tarnished actors are kept secret from the public, thereby shielding mediators from negative reactions in world opinion, until they reach a breakthrough. This method was effectively used in the context of the 1993 Oslo Peace Accords between the PLO and the Israeli government (Elon 1993). However, as mentioned above, some observers have pointed to the deficiencies of this approach (Wanis-St. John 2006). As far as include-exclude scenarios are concerned, where mediators should involve a broad range of actors, but such inclusion complicates peace talks, mediators may opt for an option that increases popular buy-in without the negative effect of complicating the peace talks. Accordingly, instead of giving actors a direct seat at the negotiation table, mediators can launch public information campaigns as well as engage in regular consultations with important civil society stakeholders in order to provide them with a feedback loop into the negotiations (McHugh: 39-41).

From a research perspective, the framework presented in this article is but an initial step towards a better understanding of inclusion and exclusion dynamics in peace negotiations. The next step would be to look at the empirical evidence, examining the dynamics of inclusion and exclusion in a number of peace negotiations in the post-Cold War period. Given the large number of variables affecting the outcome of peace negotiations, the development of a few detailed case studies seems to be the most appropriate methodology for this purpose. Such empirical research could help to refine the inclusion-exclusion framework proposed in this article. Additionally, it could help to develop hypotheses about the dynamics of inclusion and exclusion; for example, 
why the scenarios for a given stakeholder change over time; or likewise, why in a given context normative arguments prevail over practical considerations, and vice versa.

One question that cannot be avoided, although it can hardly be resolved, is the morality of inclusion and exclusion in peace processes. Should ethical or practical considerations prevail when it comes to distributing seats in peace negotiations? The position of the author is that peace negotiations do not operate in a moral vacuum. Norms and values play a legitimate role in peace negotiations, and practical effectiveness is not the only benchmark by which mediators are evaluated. The Munich Agreement of 1938 stands as a reminder that sometimes ethical concerns should prevail over whatever practical benefits negotiations may yield in the short run. However, the threshold for such action must be extremely high. Normally, peacemaking is a pragmatic business, not least because all sides of a conflict have usually committed terrible crimes and they often accuse each other of being terrorists and war criminals. Peacemakers should be given the leeway to disregard such labels and to work with any group if it helps to build sustainable peace. Just like humanitarian workers are struggling to preserve "humanitarian space," mediators have to defend "peacemaking space" from an exaggerated projection of normative concepts and political agendas. If they do not succeed, their noble mission will be put in jeopardy. 


\section{References}

Aall, Pamela (2007). "The Power of Non-Official Actors in Conflict Management," in Chester A. Crocker, Fen Hampson, and Pamela Aall, editors, Leashing the Dogs of War: Conflict Management in a Divided World. Washington, DC: USIP Press: 477-494.

Akhavan, Payam (2005). "The Lord's Resistance Army Case: Uganda's Submission of the First State Referral to the International Criminal Court." American Journal of International Law 99, 2: 403-421.

Axelrod, Robert (1984). The Evolution of Cooperation. New York, Basic Books. (1997). The Complexity of Cooperation. Princeton, Princeton University Press.

Babbitt, Eileen F. (2009). "The Evolution of International Conflict Resolution: From Cold War to Peacebuilding." Negotiation Journal 25, 4: 539-549.

and Ellen L. Lutz, editors (2009). Human Rights and Conflict Resolution in Context. Syracuse, NY: Syracuse University Press.

Baechler, Günther (2008). “"Emerging Archetypes': A Comparison of Patterns of Peace Processes in Sri Lanka and Nepal," in Daniela Körppen, Beatrix Schmelze and Oliver Wils, editors, A Systemic Approach to Conflict Transformation: Exploring Strengths and Limitations. Berlin: Berghof Foundation for Peace Support.

Ban, Ki-Moon (2009). Report of the Secretary-General on Enhancing Mediation and its Support Activities. UN Doc. S/2009/189. 8 April.

Barnes, Catherine (2002). "Democratizing Peacemaking Processes: Strategies and Dilemmas for Public Participation." Accord: An International Review of Peace Initiatives 13.

Barnett, Michael (2006). "Building a Republican Peace: Stabilizing States after War." International Security 30, 4: 87-112.

Bartoli, Andrea (2009). "NGOs and Conflict Resolution," in Jacob Bercovitch, Victor Kremenyuk, and I. William Zartman, editors, The SAGE Handbook of Conflict Resolution. London: SAGE, 2009: 392412.

Bathia, Michael V. (2005). "Fighting Words: Naming Terrorists, Bandits, Rebels and other Violent Actors." Third World Quarterly 26, 1: 5-22.

Beardsley, Kyle C. et al. (2006). "Mediation Style and Crisis Outcomes." Journal of Conflict Resolution 50, 1: 58-86.

Bell, Christine (2000). Peace Agreements and Human Rights. Oxford: Oxford University Press. (2006). Negotiating Justice? Human Rights and Peace Agreements. Geneva: International Council on Human Rights Policy.

Bercovitch, Jacob (2002). "Conclusion: Some Thoughts on the Process and Potential of Mediation," in Jacob Bercovitch, editor, Studies in International Mediation. New York: Palgrave MacMillan: 258265. 
(2009). "Mediation and Conflict Resolution," in Jacob Bercovitch, Victor Kremenyuk, and I. William Zartman, editors, The SAGE Handbook of Conflict Resolution. London: SAGE: 340-357.

Carr, E.H. (2001 [1939]). The Twenty Years' Crisis: An Introduction to the Study of International Relations, $2^{\text {nd }}$ edition. Basingstoke: Palgrave Macmillan.

Centre for Humanitarian Dialogue (2007). Charting the Roads for Peace: Facts, Figures and Trends in Conflict Resolution. Geneva: HD Centre.

Clapham, Christopher (1998). "Rwanda: The Perils of Peacemaking." Journal of Peace Research 35, 2: 193-210.

Chigas, Diana (2007). "Capacities and Limits of NGOs as Conflict Managers," in Chester A. Crocker, Fen Hampson, and Pamela Aall, editors, Leashing the Dogs of War: Conflict Management in a Divided World. Washington, DC: USIP Press: 553-581.

Colangelo, Anthony J. (2007). "Constitutional Limits on Extraterritorial Jurisdiction: Terrorism and the Intersection of National and International Law." Harvard International Law Journal 48, 1: 121-201.

Council of the European Union (2009). Concept on Strengthening EU Mediation and Dialogue Capacities. EU Doc. 15779/09. 10 November.

Cunningham, David E. (2006). "Veto Players and Civil War Duration." American Journal of Political Science 50, 4: 875-892.

Deng, Francis et al. (1996). Sovereignty as Responsibility: Conflict Management in Africa. Washington, DC: Brookings Institution Press.

Doyle, Michael (1983). "Kant, Liberal Legacies, and Foreign Affairs." Philosophy and Public Affairs 12, 3: 205-235.

Elon, Amos (1993). “The Peacemakers.” The New Yorker. 20 December.

Evans, Gareth and Mohamed Sahnoun (2001). "The Responsibility to Protect." Foreign Affairs 81, 2: 99110.

Fearon, James D. and David D. Laitin (2004). "Neotrusteeship and the Problem of Weak States." International Security 28, 4: 5-43.

Franck, Thomas M. (1990). The Power of Legitimacy among Nations. New York: Oxford University Press.

Fugfugosh, Miriam (2008). Operationalising Mediation Support: Lessons from Mediation Experiences in the OSCE Area. Geneva: Geneva Centre for Security Policy.

Goetschel, Laurent and Tobias Hagmann (2009). "Civilian Peacebuilding: Peace by Bureaucratic Means?" Conflict, Security and Development 9, 1: 55-73.

Greenhill, Kelly M. and Solomon Major (2006/07). "The Perils of Profiling: Civil War Spoilers and the Collapse of Intrastate Peace Accords.” International Security 22, 2: 7-40. 
Gunning, Jeroen (2004). "Peace with Hamas? The Transforming Potential of Political Participation." International Affairs 80, 2: 233-255.

Hart, Vivien (2001). "Constitution-Making and the Transformation of Conflict." Peace \& Change 26, 2: 153-176.

Hazan, Pierre (2004). "The Revolution by the ICTY: The Concept of Justice in Wartime." Journal of International Criminal Justice 2: 533-540.

Holbrooke, Richard (1998). To End a War. New York: Random House.

Huber, Konrad (2004). The HDC in Aceh: Promises and Pitfalls of NGO Mediation and Implementation. Washington, DC: East-West Center.

Human Security Centre (2007). Human Security Brief 2006. Vancouver: Human Security Centre, University of British Columbia.

Hurd, Ian (1999). "Legitimacy and Authority in International Politics." International Organization 53, 2 : $379-408$.

Ingebritsen, Christine (2002). "Norm Entrepreneurs: Scandinavia's Role in World Politics." Cooperation and Conflict 37, 1: 11-23.

International Crisis Group (2006). “Nepal: From People Power to Peace?” Asia Report No. 115, 10 May.

Jolly, Richard, Louis Emmerij, and Thomas G. Weiss (2009). UN Ideas that Changed the World. Bloomington, IN: Indiana University Press.

Kleiboer, Marieke (1994). "Ripeness of Conflict: A Fruitful Notion?” Journal of Peace Research 31, 1: 109-116.

Krasner, Stephen D. and Carlos Pascual (2005). “Addressing State Failure.” Foreign Affairs 84, 4: 153163.

Kriesberg, Louis (2001). "The Growth of the Conflict Resolution Field," in Chester Crocker, Fen Osler Hampson and Pamela Aall, editors, Turbulent Peace: the Challenges of Managing International Conflict. Washington, DC: USIP Press: 407-425.

Lanz, David (2007). The ICC's Intervention in Northern Uganda: Beyond the Simplicity of Peace vs. Justice. Working Paper. Medford, MA: The Fletcher School of Law and Diplomacy.

Lederach, John Paul (1997). Building Peace: Sustainable Reconciliation in Divided Societies. Washington, DC: USIP Press.

Luttwak, Edward N. (1999). “Give War a Chance.” Foreign Affairs 78, 4: 36-44.

Lutz, Ellen L. and Kathryn Sikkink (2001). "The Justice Cascade: The Evolution and Impact of Foreign Human Rights Trials in Latin America." Chicago Journal of International Law 2, 1: 1-34. 
McHugh, Gerry (2010). Integrating Internal Displacement in Peace Processes and Agreements. Washington, DC: Brookings Institution, United States Institute of Peace.

McGreal, Chris (2007). "Justice or Reconciliation?: African Search for Peace Throws Court into Crisis." The Guardian. 9 January.

Nathan, Laurie (2008). "Mediation in African Conflicts: The Gap between Mandate and Capacity," in Centre for Humanitarian Dialogue, Africa Mediator’s Retreat. Geneva: HD Centre: 11-22.

Neier, Aryeh (2001). “The Quest for Justice.” New York Review of Books. 8 March.

Nye, Joseph S. (2004). Soft Power: The Means to Success in World Politics. New York: Public Affairs.

Paris, Roland (2004). At War's End: Building Peace after Civil Conflict. New York: Cambridge University Press.

Raiffa, Howard (2004). Negotiation Analysis. Cambridge, MA: Belknap.

Richmond, Oliver (2004). The Transformation of Peace. London: Palgrave.

Rubin, Jeffrey Z. (1992). "International Mediation in Context," in Jacob Bercovitch and Jeffrey Z. Rubin, editors, Mediation in International Relations. London: Palgrave MacMillan: 249-272.

Samuels, Kirsti (2006). "Post-Conflict Peace-Building and Constitution-Making." Chicago Journal of International Law 6, 2: 1-20.

Schachter, Oscar (1962). "Dag Hammarskjold and the Relation of Law to Politics." American Journal of International Law 56, 1: 1-8.

Stedman, Stephen J. (1997). “Spoiler Problems in Peace Processes.” International Security 22, 2: 5-53.

(2002). "Introduction," in Stephen J. Stedman, Donald Rothchild and Elizabeth M. Cousens, editors, Ending Civil Wars: The Implementation of Peace Agreements. Boulder, CO: Lynne Rienner: $1-40$.

Supreme Court of the United States (2010). Holder, Attorney-General, et al. v. Humanitarian Law Project et al. No. 08-1498. 21 June.

Swiss Federal Department of Foreign Affairs (2007). Switzerland's Peace and Human Rights Promotion. Bern: FDFA.

Taulbee, James Larry and Marion V. Creekmore Jr. (2003). "NGO Mediation: The Carter Center." International Peacekeeping 10, 1: 156-171.

Toros, Harmonie (2008). “'We Don't Negotiate with Terrorists!': Legitimacy and Complexity in Terrorist Conflicts.” Security Dialogue 39, 4: 407-426.

UN Security Council (2008). Record of the $5979^{\text {th }}$ Meeting of the United Nations Security Council. UN Doc. S/PV/5979. 23 September. 
Wanis-St. John (2006). "Back Channel Negotiation: International Bargaining in the Shadows." Negotiation Journal 22, 2: 119-144.

and Darren Kew (2008). "Civil Society and Peace Negotiations: Confronting Exclusion." International Negotiation 13: 11-36.

Zahar, Marie-Jöelle (2003). "Reframing the Spoiler Debate in Peace Processes," in John Darby and Roger MacGinty, editors, Contemporary Peacemaking: Conflict, Violence and Peace Processes. Basingstoke, Palgrave Macmillan; 114-124.

Zartman, I. William (1989 [1985]). Ripe for Resolution: Conflict and Intervention in Africa. New York: Oxford University Press.

(2003a). "Negotiating with Terrorists." International Negotiations 8, 3: 443-450.

(2003b). "Ripeness," in Guy Burgess and Heidi Burgess, editors, Beyond Intractability. Boulder, CO: Conflict Research Consortium, University of Colorado. Available from <http://www.beyondintractability.org/essay/ripeness/> [Accessed on 18 July 2010].

and Saadia Touval (2007). "International Mediation," in Chester A. Crocker, Fen Hampson, and Pamela Aall, editors, Leashing the Dogs of War: Conflict Management in a Divided World.

Washington, DC: USIP Press: 437-454. 